\title{
Efek ekstrak daun sirsak (Annona muricata Linn) terhadap profil lipid tikus putih jantan (Rattus Norvegicus)
}

\author{
Indrawati Wurdianing ${ }^{1}$, SA Nugraheni ${ }^{2}$, Zen Rahfiludin ${ }^{2}$
}

\begin{abstract}
Background : Lipid profile effects is a risk factor for Coronary Heart Disease. Soursop leaves (Annona muricata L) is a traditional medicine plant containing metabolic compounds that contribute to the improvement of the lipid profile.

Objective : To determine the effects of soursop leaves extract on lipid profile (total cholesterol, LDL cholesterol, HDL cholesterol and triglyceride).

Methods : An experimental study using randomized pre-posttest with control group design. Sample consisted of 28 male Wistar rats, were divided into four groups. The control group (K) was only given High Fat High Cholesterol (HFHC) diet and treatment groups (P1, P2, P3) were given a HFHC diet plus Annona muricata L extract with doses of 100,200 and 300 $m g / k g B B$ per day for 28 days respectively. Data were analyzed by Wilcoxon test, Kruskal-Wallis and Mann Whitney.

Results : The mean total cholesterol level significantly decreased in the treatment group P1 $(p=0.028)$ from 60.7 mg/dl (47.675.3) to $45.5 \mathrm{mg} / \mathrm{dl}$ (38.4-62.4). Mean HDL cholesterol level significantly increased in the treatment group P2 ( $p=0.043)$ from $26.0 \mathrm{mg} / \mathrm{dl}$ (19.7-35.3) to $27.9 \mathrm{mg} / \mathrm{dl}$ (18.8-38.0). The mean levels of LDL cholesterol and triglyceride decreased but not significantly.

Conclusion : The administration of Annona muricata L extract can decrease total cholesterol and increase HDL cholesterol significantly.
\end{abstract}

Keywords: lipid profile (total cholesterol, LDL cholesterol, HDL cholesterol and triglyceride), HFHC diet, Annona muricata L

\section{ABSTRAK}

Latar Belakang : Profil lipid merupakan salah satu faktor risiko terjadinya penyakit jantung koroner. Daun sirsak merupakan tanaman obat tradisional yang mengandung berbagai senyawa metabolik yang berperan terhadap perbaikan profil lipid.

Tujuan :Mengetahui efek ekstrak daun sirsak terhadap profil lipid ( kadar kolesterol total, kolesterol LDL, kolesterol HDL dan trigliserida).

Metoda : Studi eksperimen dengan rancangan penelitian randomized pre-posttest with control group design pada 28 tikus Wistar jantan yang dibagi menjadi 4 kelompok. Kelompok kontrol (K) hanya diberikan diet tinggi lemak tinggi kolesterol dan kelompok perlakuan (P1,P2,P3) diberikan diet tinggi lemak tinggi kolesterol dan ekstrak daun sirsak dengan dosis masingmasing 100,200,dan 300 mg/kgBB per hari selama 28 hari. Analisis data yang digunakan adalah uji Wilcoxon, Kruskal-Wallis dan Mann Whitney.

Hasil : Rerata kadar kolesterol total menurun signifikan pada kelompok perlakuan P1 (p=0,028) dari 60,7 mg/dl (47,6-75,3) menjadi 45,5 mg/dl (38,4-62,4). Rerata kadar kolesterol HDL meningkat signifikan pada kelompok perlakuan P2 (p=0,043) dari 26,0 mg/dl (19,7-35,3) menjadi 27,9 mg/dl (18,8-38,0). Rerata kadar kolesterol LDL dan trigliserida menurun meskipun secara statistic tidak signifikan.

Simpulan : Pemberian ekstrak daun sirsak secara signifikan dapat menurunkan kadar kolesterol total dan meningkatkan kadar kolesterol HDL.

Kata Kunci : Profil lipid (kolesterol total, kolesterol LDL, kolesterol HDL, dan trigliserida), diet tinggi lemak tinggi kolesterol, ekstrak daun sirsak

\section{PENDAHULUAN}

Penyakit jantung koroner merupakan penyebab kematian utama di dunia. Kasus-kasus penyakit jantung dan pembuluh darah banyak menye- babkan kematian nomor satu sebesar $15 \% .^{1}$ Penyakit jantung koroner dise- babkan penyempitan pembuluh arteri yang mengalirkan darah ke otot jan- tung yang dikenal sebagai atheroscle- rosis. Aterosklerosis ini

\footnotetext{
${ }^{1}$ Balai Pelatihan Kesehatan, Kota Semarang

${ }^{2}$ Fakultas Kesehatan Masyarakat, Universitas

Diponegoro, Indonesia
}

merupakan endapan lemak dan kolesterol yang berada disepanjang dinding arteri.

Tingginya prevalensi hiperkolesterolemia menjadi alasan para peneliti melakukan kajian penelitian untuk menurunkan kadar kolesterol. Menurut Mustapa, pemberian infusa daun manggis pada konsentrasi $15 \% \mathrm{~b} / \mathrm{v}$ dan $60 \% \mathrm{~b} / \mathrm{v}$ dapat menurunkan kadar kolesterol. ${ }^{2}$ Pemberian dekok Zea mays dosis $7,7 \mathrm{ml} / \mathrm{hari}$ berpengaruh sangat nyata terhadap penurunan kadar kolesterol total, trigliseridadan kolesterol LDL serta peningkatan kadar kolesterol HDL pada tikus yang diberi diet tinggi lemak. ${ }^{3}$ 
Daun sirsak mengandung senyawa metabolik sekunder antara lain alkaloid, triterpenoid, kumarin, saponin dan flavonoid yang berperan dalam proses hipoglikemik, hipotensi, analgesik dan antiinflamatory. ${ }^{4,5,6}$ Larbie et al. mengemukakan bahwa ekstrak daun sirsak menggunakan metode dekok menghasilkan senyawa metabolik saponin, tannin, glycoside dan flavonoid. ${ }^{7}$ Senyawa metabolit tersebut seperti senyawa flavonoid dan saponin bersifat sebagai antioksidan yang berperan terhadap mekanisme perbaikan profil lipid. ${ }^{8,9}$

Hasil penelitian ini diharapkan dapat memberikan informasi kepada penderita hiperkolesterolemia dan masyarakat tentang efek pemberian ekstrak daun sirsak sebagai antihiperkolesterolemia, yang dapat menurunkan kadar kolesterol total, LDL kolesterol dan trigliserid serta meningkatkan HDL kolesterol.

\section{METODE DAN BAHAN}

Bahan yang digunakan dalam penelitian ini meliputi tikus putih (Rattus norvegicus) jantan galur Wistar berumur 10 minggu dengan berat awal 180200 gram, diet standar AD II, daging sapi dan kuning telur sebagai sumber lemak dan kolesterol, air minum, daun sirsak, air suling, alumunium foil, serum, larutan standar (kolesterol, triliserid, LDL HDL), reagen uji (kolesterol, trigliserid, LDL dan HDL).

Penelitian ini termasuk penelitian eksperimental (True Experiment Design)dengan rancangan penelitian randomized pre-posttest with control group design.

Penentuan besar sampel menggunakan ketentuan WHO yaitu jumlah sampel minimal 5 ekor tikus tiap kelompok yang diambil secara acak. ${ }^{10}$ Penelitian ini dibagi menjadi empat kelompok yaitu kelompok kontrol dan tiga kelompok perlakuan dengan jumlah sampel terdiri dari 7 ekor tikus tiap kelompok sehingga didapat total sampel sejumlah 28 ekor tikus. Kelompok kontrol (K) hanya diberi diet TLTK (tinggi lemak tinggi kolesterol) dan kelompok perlakuan (P1, P2, P3) diberi diet TLTK dan ekstrak Annona muricata $L$ dengan dosis 100, 200 dan $300 \mathrm{mg} / \mathrm{kgBB}$ per hari selama 28 hari. Diet TLTK dibuat dengan cara menambahkan lemak sapi $10 \%$ ke dalam diet standar AD II dan kolesterol 2\% berupa kuning telur yang diberikan dengan cara di sonde secara intermitten. Pengambilan darah dari pleksus retroorbitalis hewan coba pada hari ke 8 dan 29. Parameter pengujian profil lipid terdiri dari total kolesterol, LDL kolesterol, HDL kolesterol dan trigliserid.

Data yang diperoleh ditampilkan dalam bentuk median (minimum-maksimum). Jumlah sampel sedikit $(<30)$ maka uji beda profil lipid sebelum dan sesudah perlakuan menggunakan Wilcoxon sedangkan uji beda profil lipid diantara keempat kelompok perlakuan menggunakan Kruskal-Wallis, apabila hasilnya signifikan maka dilanjut analisis dalam kelompok perlakuan menggunakan Mann Whitney. Nilai signifikan dalam penelitian ini jika variabel yang dianalisis memiliki nilai $\mathrm{p}<0,05$.

\section{HASIL}

Ekstrak daun sirsak diidentifikasi golongan senyawa metabolik dengan menggunakan metode Kromatografi Lapis Tipis (KLT). Hasil penapisan fitokimia ekstrak daun sirsak menunjukkan bahwa ekstrak daun sirsak positif mengandung senyawa flavonoid dan saponin.

\section{Perubahan Profil Lipid}

Perubahan profil lipid selama 28 hari masa pemeliharaan dengan perlakuan diet yang berbeda dapat dilihat pada Gambar 1.

\section{Kolesterol Total}

Gambar 1(a) dapat dilihat rerata kadar kolesterol total diantara keempat kelompok perlakuan yang mengalami penurunan signifikan pada kelompok perlakuan P1 $(\mathrm{p}=0.028)$ yaitu dari $60.7 \mathrm{mg} / \mathrm{dl}(47.6-$ 75.3) menjadi $45.5 \mathrm{mg} / \mathrm{dl}$ (38.4-62.4). Hasil uji statistik Kruskal-Wallis menunjukkan tidak ada perbedaan yang signifikan diantara keempat kelompok perlakuan $(\mathrm{p}=0.355)$.

\section{LDL Kolesterol}

Berdasarkan Gambar 1(b) bahwa rerata kadar LDL kolesterol untuk kelompok kontrol mengalami peningkatan yaitu dari $18.9 \mathrm{mg} / \mathrm{dl} \quad(10.8-21.4)$ menjadi $19.1 \mathrm{mg} / \mathrm{dl} \quad$ (12.9-24.8). Kelompok perlakuaan P1, P2 dan P3 kadar LDL kolesterolnya mengalami penurunan tapi tidak bermakna secara statistik.

Berdasarkan uji statistik Kruskal-Wallis menunjukkan hasil tidak ada perbedaan yang signifikan diantara keempat kelompok perlakuan $(\mathrm{p}=0.596)$.

\section{HDL Kolesterol}

Perubahan kadar HDL kolesterol dapat dilihat pada Gambar 1(c) bahwa rerata kadar HDL kolesterol diantara keempat kelompok perlakuan yang mengalami peningkatan signifikan pada kelompok perlakuan P2 ( $\mathrm{p}=0.043)$ yaitu dari $26.0 \mathrm{mg} / \mathrm{dl}(19.7-$ 35.3) menjadi $27.9 \mathrm{mg} / \mathrm{dl}$ (18.8-38.0).

Berdasarkan uji statistik Kruskal-Wallis menunjukkan hasil tidak ada perbedaan yang signifikan diantara keempat kelompok perlakuan $(\mathrm{p}=0.390)$. 


\section{Trigliserid}

Hasil penelitian rata-rata kadar trigliserid sebelum aklimatisasi dan sesudah perlakuan selama 28 hari dapat dilihat pada Gambar 1(d). Hasil penelitian menunjukkan bahwa peningkatan kadar trigliserid terjadi pada semua kelompok. Kadar trigliserid yang mengalami peningkatan terbesar terjadi pada kelompok kontrol yaitu sebesar $52.7 \mathrm{mg} / \mathrm{dl}$ dari 37.4 $\mathrm{mg} / \mathrm{dl}$ (26.1-88.0) menjadi $90.1 \mathrm{mg} / \mathrm{dl}$ (59.8-150.7).

Berdasarkan uji statistik Kruskal-Wallis menunjukkan hasil tidak ada perbedaan yang

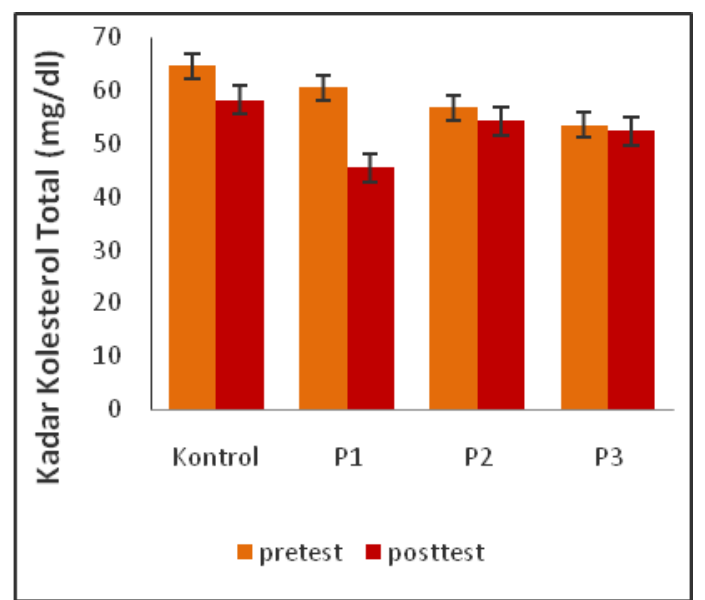

(a)

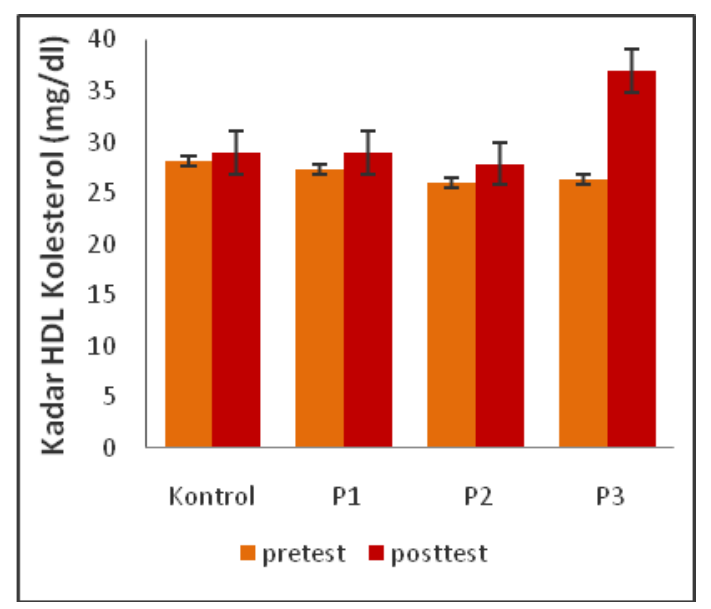

(c) signifikan diantara keempat kelompok perlakuan $(\mathrm{p}=0.849)$.

\section{PEMBAHASAN}

Konsumsi lemak berlebih bisa meningkatkan kolesterol, LDL dan trigliserid serta menurunkan HDL. Salah satu cara untuk menurunkan kolesterol, LDL dan trigliserid serta menaikkan HDL dengan mengkonsumsi makanan yang mengandung antioksidan. Daun sirsak

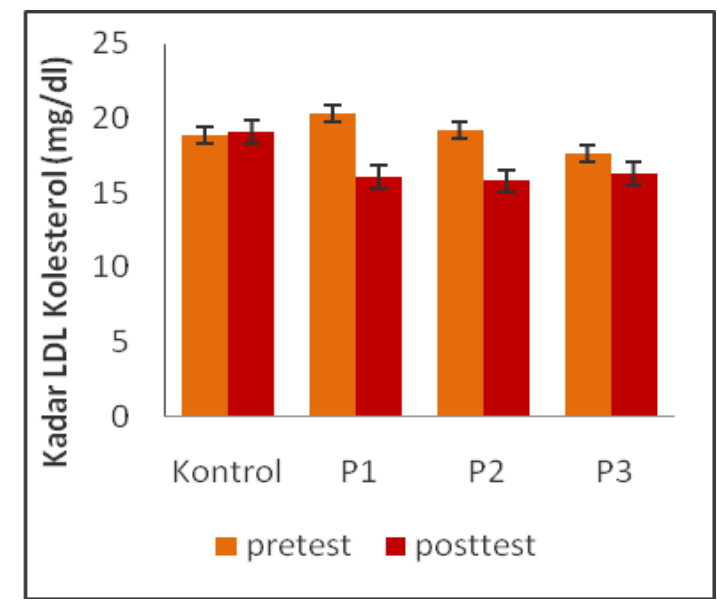

(b)

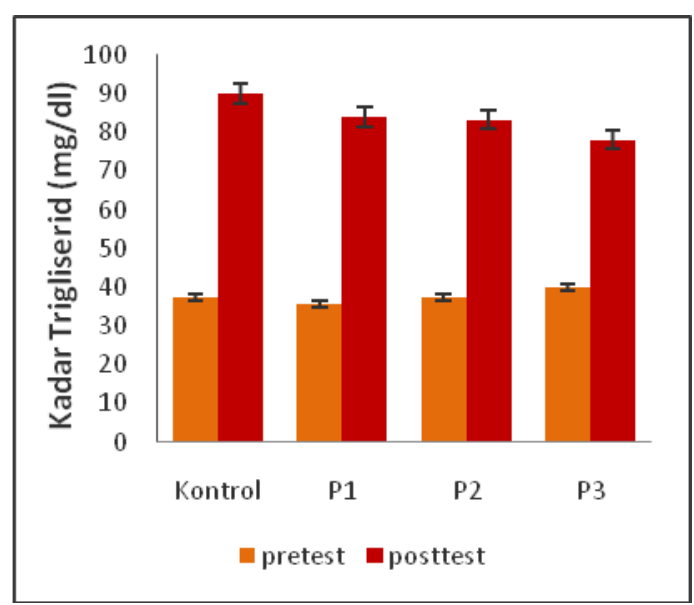

(d)

Gambar 1. Perubahan Profil Lipid Sebelum (pretest) dan sesudah (posttest) Perlakuaan. (a) Kolesterol total (b) LDL kolesterol (c) HDL kolesterol (d) Trigliserid

mengandung senyawa metabolik sekunder seperti kumarin, flavonoid, saponin, tannin ${ }^{4}$, alkaloid ${ }^{5}$, dan triterpenoid ${ }^{6}$ yang berfungsi sebagai antioksidan.

Pemberian diet tinggi lemak dan tinggi kolesterol pada penelitian Kovar et al, diet kolesterol $2 \%$ dan lemak sapi $5 \%$ selama 2 minggu menyebabkan hiperkolesterolemia sampai $5 \mathrm{mmol} / \mathrm{l}$ pada tikus wistar. ${ }^{11}$ Hasil penelitian ini berbeda dengan penelitian Kovar et al dimana hasil kadar kolesterol totalnya mengalami penurunan tapi tidak signifikan.
Hal ini disebabkan dalam penelitian ini sumber kolesterolnya menggunakan kuning telur segar dan sumber lemaknya berasal dari daging sapi. Menurut Valenzuela et al bahwa kuning telur segar mengandung kolesterol sebanyak 0.2-0.22g/100g. Telur yang diolah dengan suhu tinggi merupakan sumber oxysterol tetapi tidak untuk kuning telur segar. ${ }^{12}$ Rata-rata kadar lemak dari daging adalah $10 \%$ berat basah dimana komponen utamanya adalah 
trigliserid dan fosfolipid sedangkan kolesterol hanya sedikit $50-89$ mg. ${ }^{12}$

Lemak diserap tubuh diubah menjadi asam lemak dan trigliserid, sehingga semakin banyak yang dimakan akan menyebabkan perubahan kadar trigliserid yang banyak.

Berdasarkan identifikasi kualitatif senyawa metabolik bahwa ekstrak daun sirsak mengandung saponin dan flavonoid. Hal ini didukung oleh Larbie et al bahwa hasil skrining fitokimia ekstrak air daun sirsak mengandung tannin, glikosid, saponin dan flavonoid. ${ }^{7}$ Penurunan kolesterol disebabkan kandungan senyawa metabolik yang terdapat dalam ekstrak daun sirsak.

Menurut Wilcox et al dan Malinow et al bahwa saponin berperan menghambat penyerapan kolesterol di usus. ${ }^{13,14}$ Konsekuensi penghambatan penyerapan kolesterol adalah kolesterol dikeluarkan dari tubuh bersama feses yang merupakan lintasan utama untuk mengeluarkan kolesterol.

Berdasarkan penelitian yang dilakukan oleh Messina dan Lee et al bahwa saponin akan berikatan dengan asam empedu dan meningkatkan ekskresi asam empedu di dalam feses dan sterol netral (seperti koprostanol dan kolestanol). ${ }^{15,16} \mathrm{Hal}$ ini menyebabkan konversi kolesterol menjadi asam empedu sangat meningkat untuk upaya mempertahankan depot asam empedu. Konsekuensinya, reseptor LDL dari hati akan dinaikkan sehingga terjadi peningkatan pengambilan LDL yang akan disertai dengan penurunan kadar kolesterol plasma. Senyawa metabolit flavonoid terbukti dapat menghambat sekresi apoB dan membantu meningkatkan ekspresi reseptor LDL (LDL $r$ ) di jaringan serta terjadi peningkatan penyerapankolesterol dalam LDL kolesterol sehingga kadar kolesterol dalam LDL kolesterol di darah menurun. ${ }^{17,18}$ Kemampuan LDL $r$ berkorelasi negatif dengan LDL kolesterol, ketika LDL $r$ lebih banyak maka LDL kolesterol sedikit. Bertambahnya jumlah reseptor LDL menyebabkan peningkatan penyerapan kolesterol LDL dari darah. ${ }^{19,20}$

Selain menurunkan kadar kolesterol total, ekstrak daun sirsak mampu meningkatkan kadar HDL kolesterol. HDL ini berperan mengangkut kolesterol dari jaringan perifer dan diuraikan kembali di dalam hati. ${ }^{21}$ Penelitian mengguna- kan flavonoid menunjukkan bahwa terjadi peningkatan aktivitas lecithin cholesterol acyl transferase (LCAT). ${ }^{22}$ LCAT merupakan enzim yang mengubah kolesterol bebas menjadi ester kolesterol dan sangat penting untuk pematangan metabolisme HDL. ${ }^{21}$ Ester kolesterol yang dikumpulkan oleh HDL kolesterol dikembalikan ke hati. ${ }^{19}$

Menurut Sato et al bahwa saponin menghambat aktivitas pancreatic lipase dan menghambat penyerapan asam lemak bebas. ${ }^{23}$ Lipase pankreas berfungsi untuk menghidrolisis asam lemak dari semua rantai panjang dari posisi 1 dan 3 gugus gliserol pada triasilgliserol sehingga menghasilkan asam lemak bebas dan 2- monoasilgliserol. Di dalam sel epitel usus, asam lemak dan 2- monoasilgliserol digabung kembali oleh reaksi enzimatik untuk membentuk triasilgliserol. Jadi penghambatan aktivitas lipase prankreas berdampak menurunnya kadar triasilgliserol di usus. Pengaruh ekstrak daun sirsak terhadap trigliserid pada kelompok perlakuan sudah terlihat tapi belum bermakna secara statistik.

Dosis $100 \mathrm{mg} / \mathrm{KgBB} / \mathrm{hari}$ lebih efektif untuk menurunkan kolesterol dibanding dosis 200 $\mathrm{mg} / \mathrm{KgBB} / \mathrm{hari}$ dan $300 \mathrm{mg} / \mathrm{KgBB} / \mathrm{hari}$. Hal ini didukung dengan penelitian Larbie et al dimana dosis $100 \mathrm{mg} / \mathrm{KgBB} / \mathrm{hari}$ lebih optimal menurunkan kadar kolesterol total dibanding dosis $1000 \mathrm{mg} / \mathrm{KgBB} /$ hari. $^{7}$ Flavonoid dapat diserap saluran pencernaan maksimal tidak lebih dari $1 \mu \mathrm{mol} / \mathrm{L} \cdot{ }^{24}$ Selain itubertambahnya dosis tidak akan meningkatkan efek namun akan memberikan dampak yang tidak diinginkan. Hal ini sesuai dengan hasil penelitian Wang et al dimana dosis rendah memberikan efek protektif namun dosis tinggi memberikan dampak hepatotoxic. ${ }^{25}$ Daun sirsak bermanfaat untuk menurunkan kolesterol pada dosis $100 \mathrm{mg} / \mathrm{kgBB} / \mathrm{hari}$ setara dengan 5 lembar daun sirsak basah sedangkan untuk menaikkan HDL kolesterol dosis $200 \mathrm{mg} / \mathrm{kgBB} /$ hari setara dengan 10-11 lembar daun sirsak basah.

Ekstrak air daun sirsak bermanfaat terhadap profil lipid namun harus memperhatikan efek toksik atau efek merugikan yang tidak diinginkan dari daun sirsak tersebut.Menurut Adewole et al bahwa ekstrak daun sirsak menggunakan metode ekstraksi maserasi pelarut air perbandingan $1: 2,5$ pemberian melalui intraperitoneal sudah memberikan efek toksik pada tikus dengan dosis $200 \mathrm{mg} / \mathrm{kgBB} /$ hari. ${ }^{4}$ Ekstrak alkohol daun sirsak pada dosis $100 \mathrm{mg} / \mathrm{kg}$ tidak menunjukkan efek toksik atau efek samping pada tikus sedangkan pada dosis $300 \mathrm{mg} / \mathrm{kg}$ sudah memberikan efek penurunan perilaku eksploratif dan konstraksi perut ringan. ${ }^{26}$ Studi toksisitas ekstrak daun sirsak menggunakan metode ekstraksi dekok pelarut air perbandingan 1:10 secara oral dosis $5 \mathrm{~g} / \mathrm{kgBB} /$ hari baru menghasilkan efek toksik atau efek yang tidak diinginkan. ${ }^{7}$

\section{SIMPULAN}

Pemberian ekstrak Annona muricata $L$ dapat menurunkan kolesterol total dan meningkatkan HDL kolesterol secara signifikan. Daun sirsak bermanfaat untuk menurunkan kolesterol pada dosis 100 $\mathrm{mg} / \mathrm{kgBB}$ setara dengan 5 lembar daun sirsak basah sedangkan untuk menaikkan HDL kolesterol dosis 
$200 \mathrm{mg} / \mathrm{kgBB}$ setara dengan 10-11 lembar daun sirsak basah berdasarkan perhitungan hasil ekstraksi daun sirsak.

\section{DAFTAR PUSTAKA}

1. Dinas Kesehatan Kota Semarang. Profil Dinas Kesehatan Kota Semarang Tahun 2010. Semarang: Dinas Kesehatan Kota Semarang; 2010.

2. Mustapa M.A. Pengaruh pemberian infuse daun manggis terhadap kadar kolesterol darah mencit jantan. Jurnal Health \& Sport. 2011 Agust; 3(1):199-84.

3. Utariningsih. Dekok Rambut Jagung (Zea mays) Efektif dalam Menurunkan Kadar Kolesterol Tikus Putih (Rattus norvegicus). Malang: PKM UMM; 2007.

4. Adewole SO and Ojewole JAO. Immunohistochemical and Biochemical Effect of Annona muricata linn (Annonaceae) Leaf Aqueous Extrac on Pancreatic $\beta$-cell of Streptozotocin-treated Diabetic Rats. Pharmacologyonline. 2006; 2:335-55.

5. Sangi M, Runtuwene M, Simbala $H$ dan Makang V. Analisis Fitokimia Tumbuhan Obat di Kabupaten Minahasa Utara. Chem. Prog. 2008; $1(1)$.

6. Muzakir. Karakterisasi simplisia dan isolasi senyawa steroid/triterpenoid dari ekstrak $n$ heksana daun sirsak (annona muricata linn.).Fakultas Farmasi: USU digital library; 2010.

7. Larbie C, Arthur, Woode E and Terlabi EO. Evaluation of Acute and Subchronic Toxicity of Annona Muricata (Linn) Aqueous Extract in Animal. European Journal of Experi mental Biology. 2011;1(4):115-24.

8. Hollman PC and Katan MB. Absorption, Metabolism and Health Effects of Dietary Flavonoid in Man. Biomed Pharmacother. 1997;51(8):305-10.

9. Grassi D, Desideri G and Ferri C. Flavonoid : Antioksidans Against Atheroschlerosis. Nutrients. 2010;2:889-02.

10. WHO. Research Guidelines for Evaluating The Safety and Efficacy of Herbal Medicines. Manila: World Health Organization Regional Office for The Western Pacific; 1993. p.35.

11. Kovar J,Tonar Z, Heczkova M, and Poledne R. Prague Hereditary Hypercholesterolemic (PHHC) Rat a Model of Polygenic Hypercholesterolemia. Physiol. Res. 2009; 58 (Suppl. 2):S95-S9.
12. Valenzuela A, Sanhueza J, and Nieto S. Cholesterol Oxidation: Health Hazard and The Role of Antioxidants in Prevention. Biol Res. 2003;36:291-02.

13. Wilcox EB. and Galloway LS. Serum and Liver Cholesterol, Total Lipids and Lipid Phosphorus Levels of Rats under Various Dietary Regimens. The American Journal of Clinical Nutrition. 1961;9:236-43.

14. Malinow MR, McLaughlin P, Papworth L, Stafford C, Kohler GO, Livingston AL and Cheeke PR. Effect of Alfalfa saponins on intestinal cholesterol absorption in rats. The American Journal of Clinical Nutrition. 1977;30:2061-7.

15. Messina MJ. Legumes and Soybeans: Overview of their Nutritional Profiles and Health Effects. American Journal of Clinical Nutrition. 1999;70:439S-50S.

16. Lee S, Simons AL, Murphy PA and Hendrich S. Soyasaponins Lowered Plasma Cholesterol andIncreased Fecal Bile Acids in Female Golden Syrian Hamsters. Experimental Biology and Medicine. 2005; 230: 472-8.

17. Borradaile NM, de Dreu LE, and Huff MW. Inhibition of Net HepG2 Cell Apolipoprotein B Secretion by the Citrus Flavonoid Naringenin Involves Activation of Phosphatidy linositol 3Kinase, Independent of Insulin Receptor Substrate-1 Phosphorylation. Diabetes.2003;52 (10): 2554-61.

18. Morin B, Nichols LA, Zalasky KM, Davis JW, Manthey JA, and Holland LJ. The Citrus Flavono- ids Hesperetin and Nobiletin Differentially Regulate Low Density Lipoprotein Receptor Gene Transcription in HepG2 Liver Cells. J. Nutr. 2008 Jul;138(7):1274-81.

19. Marks DB, Marks AD and Smith CM. Biokimia Kedokteran Dasar: Sebuah Pendekatan Klinis (Basic Medical Biochemistry:AClinical Approach). Alih Bahasa Bra ham U. P endit. Jakarta: EGC; 2000.

20. Musa HH, Cheng XS, Wu HPJ, Meki DM, and Chen GH. Analysis of LDL Receptor mRNA Expression, Serum Biochemical and Abdominal Fat Weight and Lean Chicken. J. Biological Sci. 2007;7:693-6.

21. Lee S, Joo H, Kim CT, Kim IH, and Kim Y. High Hydrostatic Pressure Extract of Garlic Increases The HDL Cholesterol Level Via UpRegulation of Apolipoprotein A-I Gene Expression in Rats Fed A High-Fat Diet. Lipids Health Dis. 2012;11:77.

22. Sudheesh S, Presannakumar G, Vijayakumar S, and Vijayalaksh- mi NR. Hypolipidemic Effect 
of Flavonoids from Solanum Melo- ngena. Plant Foods for Human Nutrition. 1997;51:321-30.

23. Sato $M$, Ueda $T$, Nagata $K$, Shiratake $S$, Tomoyori H, Kawakami M et al. Dietary kakrol (Momordica dioica roxb.) flesh inhibits triacylglycerol absorption and lowers the risk for development of fatty liverin rats. Experimental Biology and Medicine. 2011; 236: 1139-46.

24. Halliwell B, Rafter J, and Jenner A. Health Promotion by Flavonoids, Tocopherols, Tocotrienols, and Other Phenols: Direct or
Indirect Effects? Antioxidant or Not? Am J Clin Nutr. 2005;81(suppl):268S-76S.

25. Wang JB, Zhao HP, Zhao YL, Jin C, Liu DJ, Kong WJ, et al. Hepato toxicity or Hepatoprotection? Pat tern Recognition for the Paradoxical Effect of the Chinese Herb Rheum palmatum L. in Treating Rat Liver Injury. PLoS One. 2011;6(9):e24498.

26. Taylor L. Technical Data Report for Graviola (Annona muricata). In Herbal Secretes of The Rainforest. 2nd ed. Austin: Sage press; 2002. 